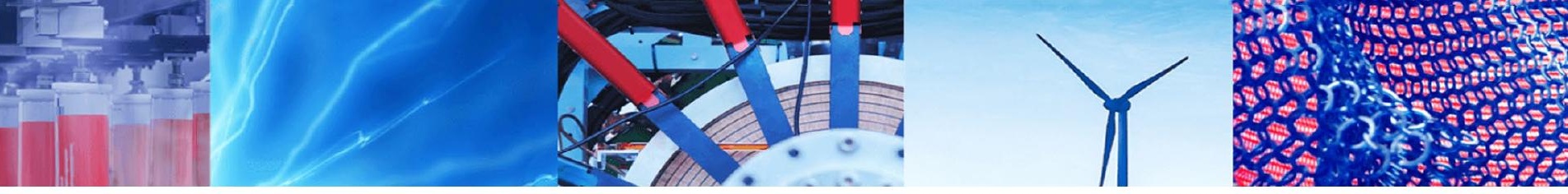

Research Article

\title{
Impact of haze events on airborne bacterial consortia-a case study
}

\author{
S. M. N. K. Thilakarathne ${ }^{1}$ (D) A. Ekanayake ${ }^{1}$ (D) P. S. Madamarandawala ${ }^{1}$ (D) W. B. C. P. Weerarathne ${ }^{1}$ (D) \\ C. A. Thotawatthage ${ }^{1}$ (D) D. N. Magana-Arachchi ${ }^{1}$ (i)
}

Received: 17 September 2020 / Accepted: 21 December 2020 / Published online: 7 January 2021

(c) The Author(s) $2021 \quad$ OPEN

\begin{abstract}
Transboundary haze events received a noticeable attention recently, due to their frequent occurrences. They are mainly, consequences of anthropogenic activities. Sri Lanka experienced a haze event parallel to India in November 2019, the first air pollution event in Sri Lanka linked to a haze event in India. Due to the limited availability of information on hazerelated microorganisms, we conducted this study in Kandy, Sri Lanka, aiming to explore the airborne bacterial consortia during a haze event. The natural sedimentation method was used for air sampling. Bacterial identification and the total bacterial load were determined using Sanger sequencing and qPCR. Notably, the total bacterial load was elevated by $\sim 40 \%$ with the haze and decreased with decreasing haze intensity. The highest bacterial load was reported during the day time of the most intense hazy day $\left(1.89 \times 10^{6} \mathrm{cells} / \mu \mathrm{l}\right)$ compared to non-hazy days (lowest; $\left.1.12 \times 10^{5} \mathrm{cells} / \mu \mathrm{l}\right)$. Twelve bacterial species were identified and the most abundant phylum was Proteobacteria. The most common species observed during haze was Acinetobacter modestus. The percentage of culturable bacterial species was also high during the haze event ( $75 \%$ during day time of the most intense hazy day compared to $25 \%$ on the control). Two human pathogenic bacteria Burkholderia multivorans and Chryseobacterium gleum were found only during the haze event. Therefore, haze events could be hazardous to humans by means of the presence and fluctuating amounts of pathogenic bacteria. Thus, these findings are important in developing policies and guidelines to monitor and minimize the negative impact of haze events.
\end{abstract}

Keywords Haze event $\cdot$ Airborne bacteria $\cdot$ Bacterial load $\cdot$ Air quality monitoring

\section{Introduction}

Over the last decade, globally, haze events have become a topic of prime concern. They are defined as events of unexpected rise of dry particulate matter (PM) in the atmosphere obscuring its clarity [1]. Farming practices involving burning of straw stubble, open coal-fired power plants and forest fires have been identified as immediate reasons for recent haze events [2, 3]. In addition, long-term effects of other anthropogenic activities such as dump sites, factory effluent and combustion of fossil fuels could also be contributing factors [3]. Hazardous pollutants released to the air in this way may get transported through dry smoggier winds to neighboring countries resulting in haze events that cross international boundaries, as was seen in Indonesia, Malaysia and China in 1997, 2005 and 2013 [4]. There is evidence that forest fires in Sumatra had links to the September 2019 haze event in Malaysia [5]. Similarly, Saudi Arabian dust storms also are known to have associations with haze events in India [6]. Such an event occurred in 2015 and resulted in 100,000 premature deaths across Indonesia,

Supplementary Information The online version contains supplementary material available at https://doi.org/10.1007/s42452-020-04022 -0 .

D. N. Magana-Arachchi, dhammika.ma@nifs.ac.Ik | ${ }^{1}$ National Institute of Fundamental Studies, Hantana Rd, Kandy 20000, Sri Lanka. 
Malaysia and Singapore [7]. Thus, these events pose a severe impact to public health and the absence of global agreements on monitoring and controlling may result in an increasing threat in the near future.

Sri Lanka, a country with less experience with haze events, was exposed to such an event in November 2019, parallel to the haze event in Delhi, India which was a top news at the time [8]. This was the first time that an air pollution incident in Sri Lanka was linked to a haze event in India. The most acceptable explanation for this is a haze event that crosses international boundaries. Air pollution in one area can affect the air quality in the adjoining areas causing damage in many ways as air cannot be kept constrained or divided between international boundaries [2]. The main reason behind the November haze event in India was stubble and paddy burning [9]. During this event, the $\mathrm{PM}_{2.5}$ values were as high as $1000 \mu \mathrm{g} / \mathrm{m}^{3}$ in Delhi and its suburbs, while the limit of safety is $60 \mu \mathrm{g} / \mathrm{m}^{3}$ [10]. In Sri Lanka, this condition was first observed in Colombo (the capital city) and then all around the country in varying intensities. Haze was observed in Kandy, a district important in terms of economy, tourism and administration, and it was predicted that the effect could be intense as Kandy is one of the most air-polluted cities in Sri Lanka [11]. As per the central environmental authority of Sri Lanka, in both Colombo and Kandy, the air quality index showed $\mathrm{PM}_{10}$ values close to $100 \mu \mathrm{g} / \mathrm{m}^{3}$ which is usually the double of a normal day [12].

Even though the physicochemical properties associated with haze events have been studied, less is known about bioaerosols, the type of particles released from marine and terrestrial eco-systems into the atmosphere $[5,13]$. They may contain both living and non-living components, wherein microorganisms may compose the living component and the types of microorganisms may depend on the source of the bioaerosols. Even in Sri Lanka, chemical and physical parameters of air pollution are monitored by the relevant institutes but changes in microbial consortia are not monitored [12]. A study done in China has identified that bacterial concentration shows a positive correlation with haze intensity $[1,14]$, but several other studies have identified a decrease $[15,16]$. Certain microbial species were also noted as being associated with haze events such as Halomonas and Shewanella species [1], but some studies have not identified any specific microorganism associated with haze events [17]. Moreover, information on the impact of haze-associated bacteria on respiratory diseases and allergies are also less explored. With reference to the November 2019 haze event in India and Sri Lanka, no studies were reported in the context of microorganisms, and hence, we undertook a study in Kandy, Sri Lanka, to assess the change in bacterial consortia due to haze conditions using advanced molecular laboratory techniques.

\section{Materials and methods}

\subsection{Sampling site, Sample collection and processing}

Air samples were collected during the haze event (06-09 November 2019) and two non-hazy days (13 and 14 November 2019) at the premises of the National Institute of Fundamental Studies, (a research institute) located in Kandy, Sri Lanka ( $7^{\circ} 17^{\prime} 02.4^{\prime \prime} \mathrm{N} 80^{\circ} 37^{\prime} 57.1^{\prime \prime}$ E). The sampling site is located $1.7 \mathrm{~km}$ away from Kandy city and is surrounded with medium vegetation density, less traffic and minimal air pollution sources. For air sample collection, the natural sedimentation method (NSM) was used, using Luria Bertani (LB) media and Whatman No.5 filter papers. In addition, two other active methods were used for confirmation of results. Detailed descriptions of the NSM and sample processing are summarized in Fig. 1, and detailed descriptions of active methods are summarized in the supplementary Fig. 1. Filter papers used in both the active and passive sampling were cut into small pieces aseptically. These pieces were suspended in sterile Milli-Q water and were shaken in an orbital shaker (ORBITEK, Scigenics Biotech, India) for $2 \mathrm{~h}$. Following extraction of bacteria into Milli-Q water, extracts were centrifuged at $12,000 \mathrm{rpm}$ for $5 \mathrm{~min}$. The supernatants were discarded having $1 \mathrm{~mL}$ of sedimented bacteria remaining for further applications [18].

\subsection{Quantification of bacteria}

Genomic bacterial DNA was extracted from the filter paper extracts using the modified Boom's method [20] and amplified using real-time Polymerase Chain Reaction (PCR) (RotorGeneQ, Qiagen, Germany). Total bacterial load in each sample was detected amplifying the $16 \mathrm{~S}$ rRNA gene of bacteria using a forward primer, $5^{\prime}$-TCC TACGGGAGGCAGCAGT-3', reverse primer, 5'- GGACTA CCAGGGTATCTAATCCTGTT-3' and a fluorescent probe (6-FAM)-5'-CGTATTACCGCGGCTGCTGGCAC-3'-(TAMRA) [21]. The $P C R$ reaction was performed in a total volume of $25 \mu \mathrm{L}$ consisting of $1 \times \mathrm{PCR}$ buffer, $1.5 \mathrm{mM} \mathrm{MgCl}$, $0.1 \mathrm{mM}$ of each dNTP, $400 \mathrm{nM}$ of each primer and $175 \mathrm{nM}$ of a fluorogenic probe in the presence of 1 unit of Taq polymerase enzyme. The amplification reaction conditions were $50^{\circ} \mathrm{C}$ for $2 \mathrm{~min}, 95^{\circ} \mathrm{C}$ for $10 \mathrm{~min}$ and 40 cycles of $95^{\circ} \mathrm{C}$ for $15 \mathrm{~s}$ and $60^{\circ} \mathrm{C}$ for $1 \mathrm{~min}$. Bacterial load in each sample was quantified in comparison with a standard curve generated by Escherichia coli DNA.

The percentage elevation of the bacterial load was calculated by taking the average bacterial load of each sampling method. Results were subjected to normality 
Fig. 1 Outline of air sample collection and processing methodology (CTAB; Cetyl trimethylammonium bromide, DNA; Deoxy ribonucleic acid, PCR; polymerase chain reaction). ${ }^{\mathrm{a}}$ Reference; [19]. ${ }^{\mathrm{b}}$ Reference; [20]

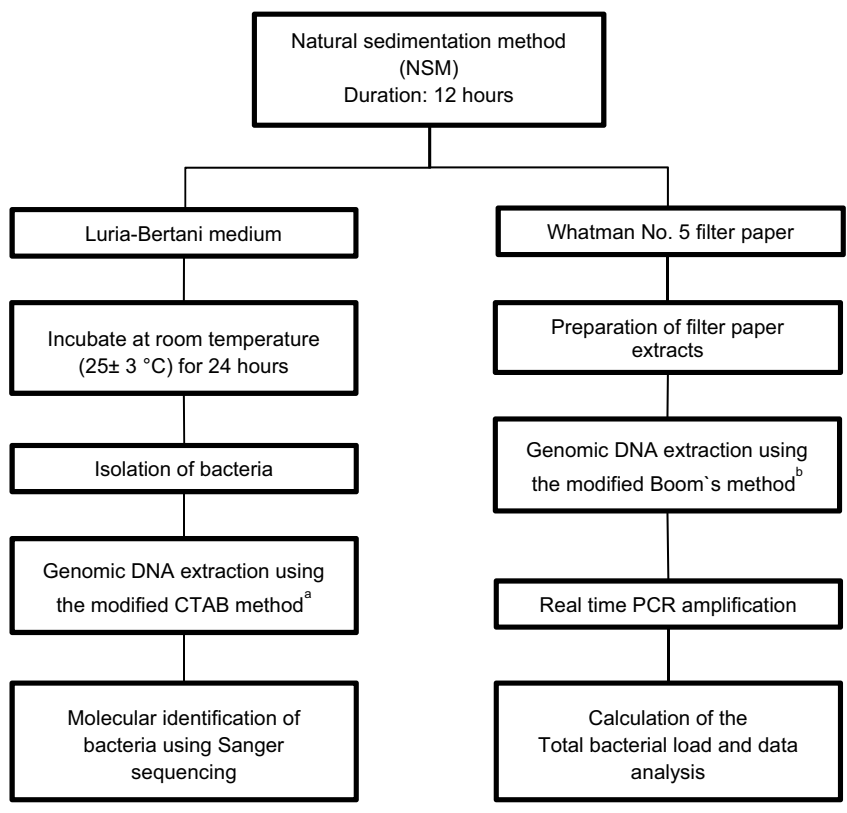

haze intensity. Proteobacteria were the dominant bacterial phylum, wherein Burkholderia multivorans and Chryseobacterium gleum, two known human pathogens, were recovered only during the hazy days.

Figure 2 and Supplementary Table 1 summarize the variation of the total bacterial load from each air sample collected during the study period. Accordingly, the highest bacterial load during the night time $(6.00 \mathrm{pm}-6.00$ am the following day) was observed on 06 November, whereas that of the day time ( $6.00 \mathrm{am}$ to $6.00 \mathrm{pm})$ was observed on 07 November, which had the most intense haze $\left(\mathrm{PM}_{2.5} \sim 60 \mu \mathrm{g} / \mathrm{m}^{3}, \mathrm{PM}_{10} \sim 100 \mu \mathrm{g} / \mathrm{m}^{3}\right.$ [12]). The lowest bacterial load during the night was observed on 13 November, which was a non-hazy day and the lowest bacterial load with respect to day time was seen on 14 November (PM2.5 $15 \mu \mathrm{g} / \mathrm{m}^{3}$, PM10 $\left.25 \mu \mathrm{g} / \mathrm{m}^{3}[11]\right)$, a day without any visible haze. These two days were considered control days in the sampling process. Notably, the bacterial load decreased from 06th to 08th November, in both the night time and day time. The outcome of the two active methods used were similar to NSM as they also showed a decrease in total bacterial load with decreasing haze intensity. The significance is that the bacterial load observed during the night time as well as the day time on control days for all sampling methods were lower than that of the hazy days. The bacterial load of a NSM plate kept for $24 \mathrm{~h}$ on a control day, was yet lower than a plate kept for $12 \mathrm{~h}$ on a hazy day. The bacterial load observed during the haze event using NSM plates was $55.8 \%$ higher than that of the controls while those from a fine particulate air sampler and a laboratory-designed air sampler were 41.8 and $51 \%$ higher than a non-hazy day, respectively. However, no 
Haze intensity

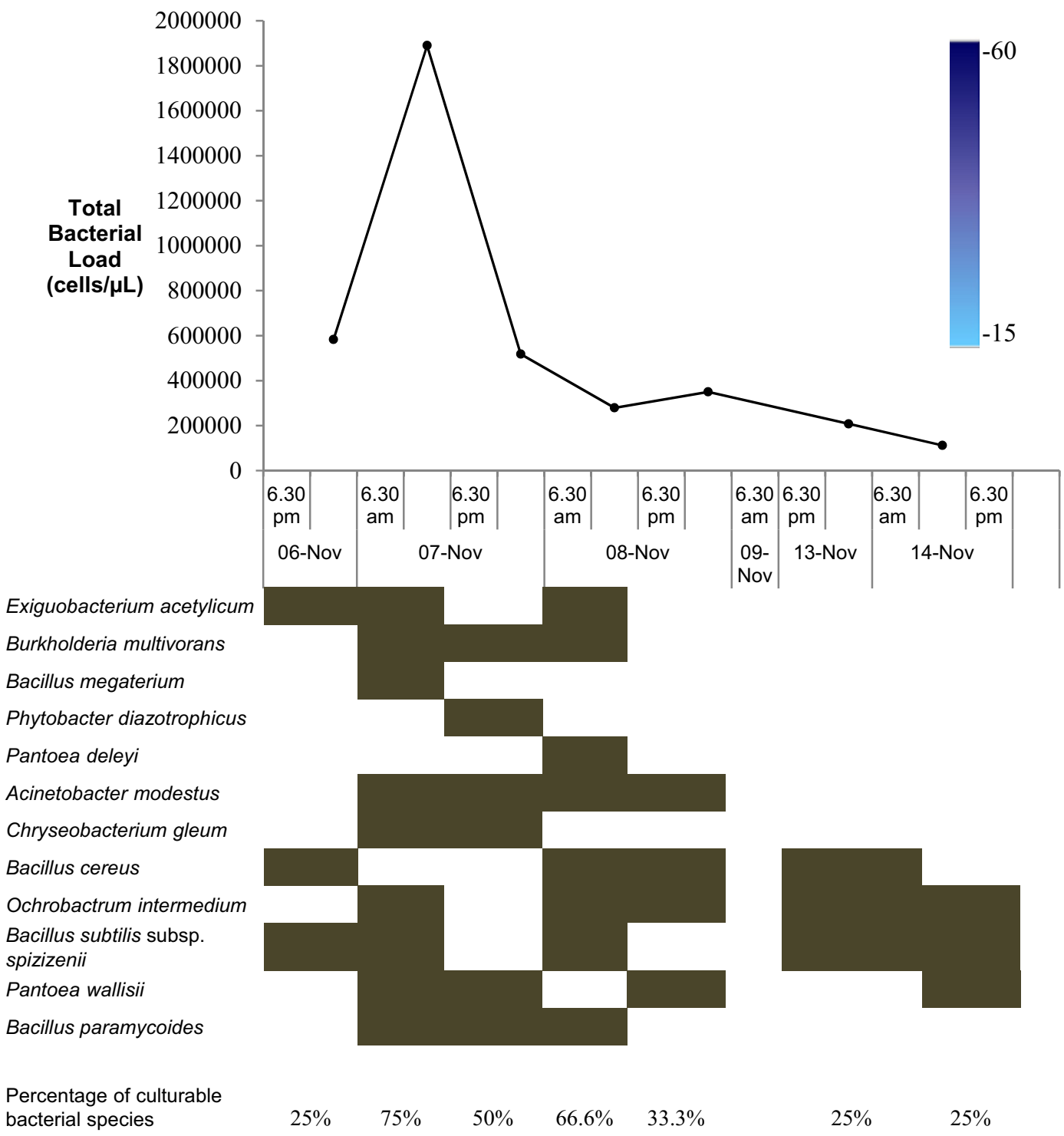

Fig. 2 A descriptive diagram of the variation of bacterial load with haze intensity and the bacterial species identified as per the date of the sample collection. The haze intensity grid was prepared as per

significant variation of the bacterial load was evident between night and day time and none of the observations were statistically significant. Consistent with some studies in China, the observations show that airborne bacterial load increases with the intensity of the haze condition and vice versa $[1,14]$. As discussed before, certain studies show a decrease. Perhaps these conflicting findings might be because of the variations in the geographical setting, culture media, seasonal changes and the techniques used. Besides, certain studies have used the PM2.5 data in the central environmental authority web site [12]. All dates refer to 2019 and the scale is based on approximate PM2.5 values in $\mu \mathrm{g} / \mathrm{m}^{3}$

only the culturable counts to predict the association, which is not a true representative of the whole picture [15]. A recent study shows that the bacterial cell counts increase with increasing PM; hence, polluted air consists of higher cell counts than that of non-polluted air [23]. High concentrations of air pollutants during a haze event provide nutrients like sulfur, nitrogen and ammonia for the growth and survival of certain bacteria thus, affecting their relative abundance [16]. Thus, the new conditions of increased/decreased components (nutrients, 
particulate matter, etc.) in the atmosphere may have resulted fluctuations in certain microorganisms, hence effecting the bacterial load.

In this study, 12 culturable bacterial species were identified. The percentage of culturable bacterial species on hazy days was observed to be slightly higher during the day time than the night time; the highest being on 07 November 2019 (75\%), the most intense hazy day (Fig. 2). It was evident throughout the study that the number of culturable bacterial species observed on hazy days was higher than that of non-hazy days (control; 25\%); however, no significant association was observed which may be due to the lack of data. This shows that haze events affect airborne bacterial diversity, which encompasses both normal airborne bacteria and bacteria accompanied by haze pollutants. Most of the identified bacterial species were from the phylum Proteobacteria [6] followed by the Firmicutes [5] and Bacteroidetes [1]. This observation can be supported by the fact that Proteobacteria are the most abundant phyla during haze events $[23,24]$ (Supplementary Table 2). Similar to a previous study based on a haze event, the most common bacterial classes observed in this study were Bacilli [5] and Gammaproteobacteria [4] [16] (Supplementary Table 2). In our study, all identified species were observed during hazy days in different combinations while only four species were observed during non-hazy days (control) (Fig. 2). The most common species observed during the studied hazy days was Acinetobacter modestus and the least common were Phytobacter diazotrophicus and Pantoea deleyi (Fig. 2). Interestingly, we also encountered a Burkholderia sp. (B. multivorans) as in a study conducted in China which encountered $B$. cenocepacia as the most abundant human pathogen during haze [23]. Bacillus subtilis subsp. spizizenii, B. cereus, Ochrobactrum intermedium and $P$. wallisii were present regardless of the haze intensity. A greater proportion of the identified bacterial species during the study were inhabitants of soil, plant and water microbiota, possibly a consequence of bacterial community movements through submicron particles and aerosolization of bacteria [16]. Bioaerosols are also capable of long range transport and hence, the microbial consortia observed in this event could be associated with the bioaerosols generated from the haze origin, but, the reality and to which percentage is yet unknown. As per literature, O. intermedium [11], B. megaterium, $B$. cereus and Exiguobacterium acetylicum [18] have been previously identified in the Kandy atmosphere; perhaps, the haze condition might have favored their survival. Certain bacteria are capable of tolerating harsh environmental conditions through mutations in their genetic makeup. This can be seen with the discussed organisms, E. acetylicum, an organism extensively studied for its multi-stress radioactive tolerance [25] and 0 . intermedium, an organism studied for its heavy metal tolerance [26]. Bacillus spp are also capable of surviving for a long time by sporulation [27].

Among the identified bacterial strains, four bacterial species were observed to have different strains with varied colony morphologies on the LB agar medium (Supplementary Fig. 2). Colony morphology variations were observed in their color, shape, margin, texture (slimy/non-slimy) and growth rate. The highest number of strains was observed in Burkholderia multivorans with five different morphologies having major differences in color and growth rate. According to the maximum likelihood (ML) tree, all the five strains of $B$. multivorans clustered together with their reference sequence (NR_029358.1) and separately from their close relative $B$. cepacia (Fig. 3). The same pattern was observed for the other three species, Bacillus cereus, $B$. subtilis subsp. spizizenii and E. acetylicum. Hence, it can be suggested that though there were different colony morphologies and sequences, the strains belong to the same species. The five different color formats observed were yellow, transparent yellow, orangish-red, pinkish opaque and whitish opaque. Further, in comparison to the growth rate, two slow-growing, one fast-growing and two moderate growing strains were observed in Burkholderia multivorans. E. acetylicum had two colony morphologies, one with a dark orange color and the other with a yellowish opaque appearance. Bacillus cereus also had two colony morphologies; colonies with a distinct wavy margin and a distinct entire margin. The major differences observed between the two strains of $B$. subtilis subsp. spizizenii was their growth rate and the texture, which varied between extremely fast-growing with dry nature and average growth rate with slimy nature. Differences in bacterial morphology, specifically the color, are a consequence of pigmentation generated within bacteria as a response mechanism to exposure to pollutants and high radiation. The higher the pollutants in the air, the greater the variety of pigmentation [28].

As mentioned earlier bacterial consortia play a major role in haze associated health threats to humans. The samples collected during the haze event consisted of four culturable human pathogenic species namely, Burkholderia multivorans, C. gleum, Bacillus cereus and O. intermedium. Among them, Burkholderia multivorans and C. gleum were found only during hazy days. The species $B$. multivorans, a member of the B. cepacia complex is reported as a multidrug-resistant pathogen causing chronic and debilitating lung infections in cystic fibrosis patients [29]. C. gleum is reported in causing infections in immunocompromised patients [30,31]. Bacillus cereus mainly causes food poisoning but is also associated with potentially lethal nongastrointestinal tract infections [32]. O. intermedium is an emerging opportunistic pathogen reported to be 


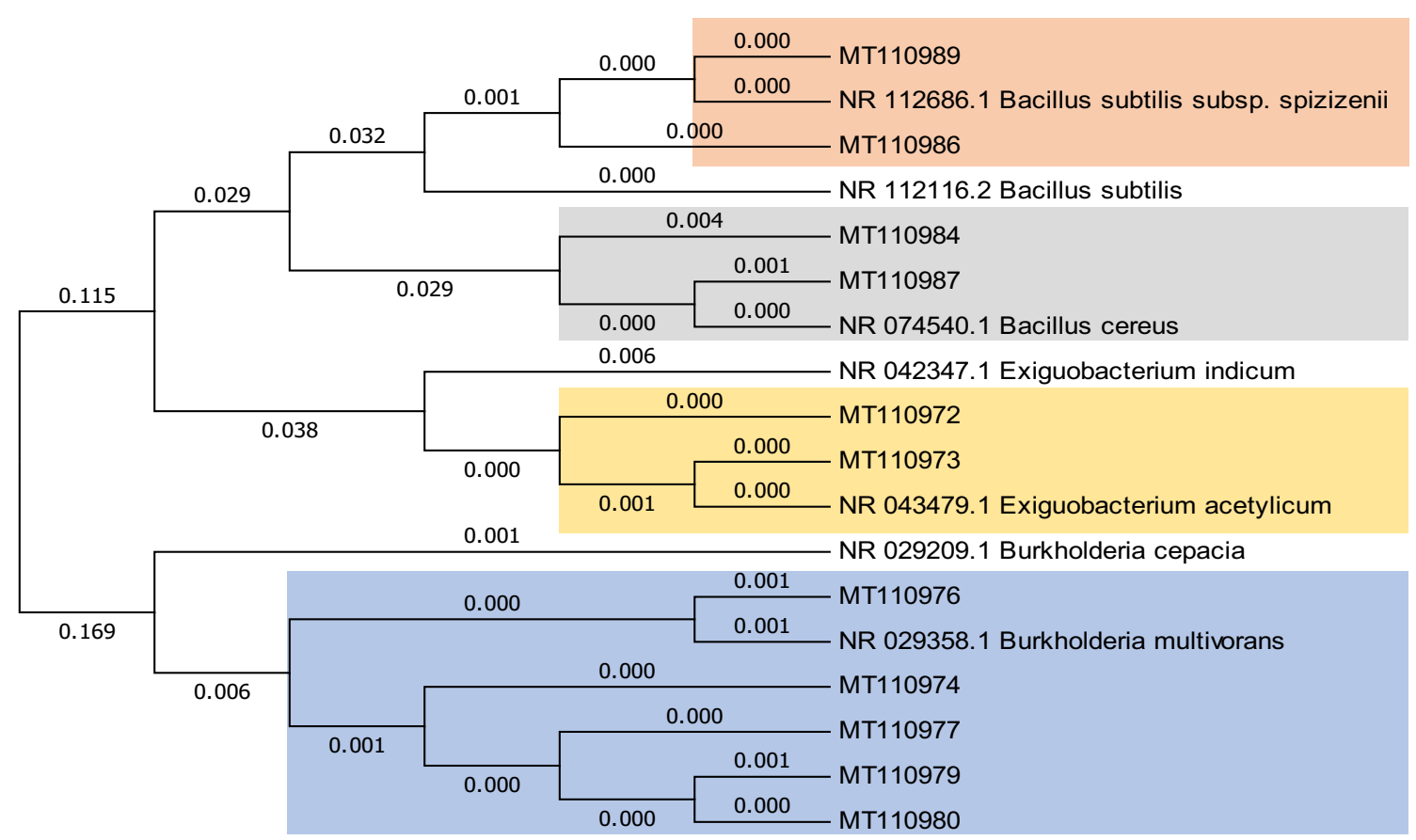

Fig. 3 Maximum likelihood (ML) tree generated for the species having morphologically (colony) varied strains (MEGA v 7.0)

associated with infective endocarditis [33]. Though not confirmed as pathogenic, Phytobacter diazotrophicus and A. modestus also have been found from clinical specimens in previous studies [34, 35]. According to the observations, it is evident that the studied haze event has had a potential impact on the health of humans in terms of encounters with pathogenic bacteria. The possibility for bacteria to acquire resistance genes due to environmental pressures is high during a haze event. Hence, it is important to study the resistance patterns and pathogenicity of these bacterial isolates to identify potential hazards.

The major limitation of the study is the low number of samples obtained, which was practically difficult as the haze event did not last long. Moreover, the study revolved only around bacteria while other microorganisms such as viruses and fungi may also show variations. However, as we conducted the analysis using molecular techniques rather than only cultures, we could obtain a complete picture on the impact of haze on airborne bacteria strengthening the study findings.

\section{Conclusion}

Conditions during a Sri Lankan haze event proved to have an impact on the airborne bacterial load which increases with the intensity of the haze condition. The study identified 12 culturable bacterial species. The highest number of culturable bacterial species (nine) and the highest amount of bacterial load $\left(1.89 \times 10^{6}\right.$ cells $/ \mu \mathrm{L}$ ) for the study were observed during the day time of the most intense hazy day, 07 November 2019. The lowest amount of bacterial load $\left(1.12 \times 10^{5}\right.$ cells/ $\mu \mathrm{L}$ ) was observed during the day time of 14 November 2019, a non-hazy day. The bacterial load observed during the haze event is $\sim 40 \%$ higher when compared to nonhazy days. Hence, these revelations should be considered when monitoring and analyzing air quality during haze conditions. The studied haze event could have been hazardous to humans in means of pathogenic bacteria. The study emphasizes the need to implement policies to control and monitor haze events and to develop guidelines on how to prevent associated diseases during haze exposure. Further studies are needed to determine the degree of pathogenicity and resistance profiles of the identified organisms. Further study of air quality is recommended to understand the conditions favoring bacterial growth during a haze event.

Acknowledgements The authors acknowledge the financial support given by National Institute of Fundamental Studies, Kandy, Sri Lanka.

Funding The research was funded by the National Institute of Fundamental Studies, Sri Lanka.

Availability of data and materials The data (sequences) that support the findings of this study are openly available in [National Center for Biotechnology Information] at https://www.ncbi.nlm.nih.gov under accession numbers [MT110972-MT110990]. 
Code availability MEGA V 7.0 [22] was used for the maximum likelihood tree generation and Minitab (release 17.1.0, State College, PA: Minitab, Inc.) was used for statistical analysis.

\section{Compliance with ethical standards}

Conflict of interest The authors have no conflicts of interest to declare that are relevant to the content of this article.

Open Access This article is licensed under a Creative Commons Attribution 4.0 International License, which permits use, sharing, adaptation, distribution and reproduction in any medium or format, as long as you give appropriate credit to the original author(s) and the source, provide a link to the Creative Commons licence, and indicate if changes were made. The images or other third party material in this article are included in the article's Creative Commons licence, unless indicated otherwise in a credit line to the material. If material is not included in the article's Creative Commons licence and your intended use is not permitted by statutory regulation or exceeds the permitted use, you will need to obtain permission directly from the copyright holder. To view a copy of this licence, visit http://creativecommons .org/licenses/by/4.0/.

\section{References}

1. Li W, Yang J, Zhang D, Li B, Wang E, Yuan H (2013) Concentration and community of airborne bacteria in response to cyclical haze events during the fall and midwinter in Beijing China. Front Microbiol 2018(9):1-12

2. Abas N, Saleem MS, Kalair E, Khan N (2019) Cooperative control of regional transboundary air pollutants. Environ Syst Res [Internet]. 8:10. https://doi.org/10.1186/s40068-019-0138-0

3. Cheong KH, Ngiam NJ, Morgan GG, Pek PP, Tan BYQ, Lai JW et al (2019) Acute health impacts of the southeast asian transboundary haze problem-a review. Int J Environ Res Public Health 16(18):3286

4. Forsyth T (2014) Public concerns about transboundary haze: a comparison of Indonesia, Singapore and Malaysia. Glob Environ Chang [Internet]. 25(1):76-86. https://doi.org/10.1016/j.gloen vcha.2014.01.013

5. Radzi Bin Abas M, Oros DR, Simoneit BRT (2004) Biomass burning as the main source of organic aerosol particulate matter in Malaysia during haze episodes. Chemosphere. 55(8):1089-95

6. Francis T, Jayakumar A, Sethunadh J, Mohandas S, Kumar S, Rajagopal EN (2020) Dust induced radiative perturbations during an episode of long-range dust transport over Delhi India: a highresolution regional NWP model study. Meteorol Atmos Phys. https://doi.org/10.1007/s00703-020-00760-3

7. Hassan A, Latif MT, Soo Cl, Faisal AH, Roslina AM, Andrea YLB et al (2017) Short communication: diagnosis of lung cancer increases during the annual southeast Asian haze periods. Lung Cancer 113:1-3. https://doi.org/10.1016/j.lungcan.2017.08.025

8. Kashin V (2020) Ecological catastrophe threatens India. Asia Africa today 4:13-18

9. Voiland A. Haze smothers Nothern India [Internet]. NASA earth observatory. 2020 [cited 2020 May 24]. Available from: https:// earthobservatory.nasa.gov/images/145827/haze-smothersnorthern-india

10. Real time ambient air quality data-Delhi pollution control committee [Internet]. [cited 2020 Nov 16]. Available from: http:// www.dpccairdata.com/
11. Weerasundara L, Amarasekara RWK, Magana-Arachchi DN, Ziyath AM, Karunaratne DGGP, Goonetilleke A et al (2017) Microorganisms and heavy metals associated with atmospheric deposition in a congested urban environment of a developing country: Sri Lanka. Sci Total Environ [Internet] 584-585:803-812. https://doi.org/10.1016/j.scitotenv.2017.01.121

12. Central Environmental Authority SL. Air quality [Internet]. 2020 [cited 2020 Aug 31]. Available from: http://www.cea.lk/web/en/ air-quality

13. Wang S, Yu S, Li P, Wang L, Mehmood K, Liu W et al (2017) A study of characteristics and origins of haze pollution in Zhengzhou, China, based on observations and hybrid receptor models. Aerosol Air Qual Res 17(2):513-528

14. Dong L, Qi J, Shao C, Zhong X, Gao D, Cao W, Chu C (2015) Concentration and size distribution of total airborne microbes in hazy and foggy weather. Sci Total Environ 541:1011-1018

15. Gao M, Yan X, Qiu T, Han M, Wang X (2016) Variation of correlations between factors and culturable airborne bacteria and fungi. Atmos Environ 128:10-19

16. Xu C, Wei M, Chen J, Wang X, Zhu C, Li J, Zheng L, Sui G, Li W, Wang W, Zhang Q, Mellouki A (2017) Bacterial characterization in ambient submicron particles during severe haze episodes at Ji'nan. China Sci Total Environ 580:188-196

17. Wei K, Zou Z, Zheng Y, Li J, Shen F, Wu C, Wu Y, Hu M, Yao M (2016) Ambient bioaerosol particle dynamics observed during haze and sunny days in Beijing. Sci Total Environ 550:751-759

18. Madamarandawala $P$, Weerasinghe $Y$, Pathiraja $D$, Ekanayake $A$, Madegedara D, Magana-Arachchi D (2019) Impact of microbial air quality in preschools on paediatric respiratory health. SN Appl Sci [Internet] 1(10):1-11. https://doi.org/10.1007/s4245 2-019-1306-6

19. Somerville W, Thibert L, Schwartzman K, Behr MA (2005) Extraction of Mycobacterium tuberculosis DNA: a question of containment. J Clin Microbiol 43(6):2996-2997

20. Boom R, Sol CJA, Salimans MMM, Jansen CL, Wertheimvan Dillen PME, Vander Noordaa J (1990) Rapid and simple method for purificaion of Nucleic acids. J Clin Microbiol. 56:495-503

21. Nadkarni MA, Martin FE, Jacques NA, Hunter N (2002) Determination of bacterial load by real-time PCR using a broad-range (universal) probe and primers set. Microbiology 148(1):257-266

22. Kumar S, Stecher G, Tamura K (2016) MEGA7: molecular evolutionary genetics analysis version for Bigger Dataset. Mol biol Evol. 33(7):1870-4

23. Ji L, Zhang Q, Fu X, Zheng L, Dong J, Wang J, Guo S (2019) Feedback of airborne bacterial consortia to haze pollution with different PM2 5 levels in typical mountainous terrain of Jinan China. Sci Total Environ 695:133912

24. Sun Y, Xu S, Zheng D, Li J, Tian H, Wang Y (2018) Effects of haze pollution on microbial community changes and correlation with chemical components in atmospheric particulate matter. Sci Total Environ 637-638:507-516

25. Oh SY, Heo NS, Shukla S, Kang S, Lee I, Lee H, Bajpai VK, Jang S, Han Y, Roh C, Huh YS (2018) Multi-stress radioactive-tolerant Exiguobacterium acetylicum CR1 and its applicability to environmental cesium uptake bioremediation. J Clean Prod 205:281-290

26. Shukla A, Parmar P, Goswami D, Patel B, Saraf M (2020) Characterization of novel thorium tolerant Ochrobactrum intermedium AM7 in consort with assessing its EPS-Thorium binding. J Hazard Mater 388:122047

27. Errington J (1993) Bacillus subtilis sporulation: regulation of gene expression and control of morphogenesis. Microbiol Rev 57(1):1-33

28. Smets W, Moretti S, Denys S, Lebeer S (2016) Airborne bacteria in the atmosphere: Presence, purpose and potential. Atmos 
Environ [Internet] 2016(139):214-221. https://doi.org/10.1016/j. atmosenv.2016.05.038

29. Flanagan JN, Kavanaugh L, Steck TR (2020) Burkholderia multivorans exhibits antibiotic collateral sensitivity. Microb Drug Resist 26(1):1-8

30. Abdalhamid B, Elhadi N, Alsamman K, Aljindan R (2016) Chryseobacterium gleum pneumonia in an infant with nephrotic syndrome. IDCases [Internet] 5:34-36. https://doi.org/10.1016/j. idcr.2016.06.004

31. Jain V, Hussain NAFA, Siddiqui T, Sahu C, Ghar M, Prasad KN (2017) Simultaneous isolation of Chryseobacterium gleum from bloodstream and respiratory tract: first case report from India. JMM Case Rep 4(10):e005122

32. Bottone EJ (2010) Bacillus cereus, a volatile human pathogen. Clin Microbiol Rev 2:382-398

33. Bharucha T, Sharma D, Sharma H, Kandil H, Collier S (2017) Ochromobactrum intermedium: an emerging opportunistic pathogen-case of recurrent bacteraemia associated with infective endocarditis in a haemodialysis patient. New microbes New Infect 15:14-15

34. Pillonetto $M$, Arend LN, Faoro H, D'Espindula HRS, Blom J, Smits THM, Mira MT, Rezzonico F (2018) Emended description of the genus Phytobacter, its type species Phytobacter diazotrophicus. Int J Syst Evol Microbiol 1:176-184

35. Nemec A, Radolfova-Krizova L, Maixnerova $M$, Vrestiakova $E$, Jezek P, Sedo O (2016) Taxonomy of haemolytic and/or proteolytic strains of the genus Acinetobacter with the proposal of Acinetobacter courvalinii sp, Acinetobacter dispersus sp (genomic species 17) Acinetobacter modestu. Int J Syst Evol Microbiol 66(4):1673-85

Publisher's Note Springer Nature remains neutral with regard to jurisdictional claims in published maps and institutional affiliations. 